\title{
Safet Kešo
}

\section{U ZRCALIMA SJEĆANJA...}

G1. ur. Ljevo-Ovčina, Amela, 2020. U zrcalima sjećanja... Zbornik radova u spomen na profesora Ilijasa Tanovića. Sarajevo: Filozofski fakultet.

Zbornik radova u spomen na profesora Ilijasa Tanovića $U$ zrcalima sjećanja... ugledao je svjetlo dana u elektronskom izdanju 2020. godine, na desetu godišnjicu od Tanovićeve smrti. Širok dijapazon naučnog interesovanja profesora Tanovića u oblastima frazeologije, leksikologije, leksikografije, semantike, metodike te svih vidova prevodilaštva, kao i opus naučnih djela koje je podario lingvističkim, a napose slavističkim krugovima u Bosni i Hercegovini i šire, nude objašnjenje za veliko interesovanje i spremnost izrazito referentnih domaćih i regionalnih lingvista, historičara i teoretičara književnosti da organizacionim naporima ili svojim prilozima učestvuju u projektu izrade i objave Zbornika.

Jednako značajan razlog ovako velikog interesovanja za učešće autora radova u kreiranju tema i sadržaja Zbornika nesumnjivo leži u njihovoj snažnoj potrebi da se putem ovog svojevrsnog hommagea Tanoviću iskaže počast i osvježi sjećanje na neponovljivo ugodnu ličnost Čovjeka s prefinjenim intelektualnim manirima, koji je kategoriju apsolutnog pedagoškog šarma živio s neopisivo prirodnom lahkoćom i jednako neusiljeno za univerzitetskom katedrom, u holu pozorišta, na ulici, u restoranu ili u svom domu.

Prvih 27 stranica Zbornika - s kojih čitamo Uvodnu bilješku, biografiju Ilijasa Tanovića, lirski toplo intonirano sjećanje na njega, te osvrt na radove u Zborniku - dolazi u cijelosti iz pera naše ugledne akademkinje, prof. dr. Marine Katnić-Bakaršić. Imajući u vidu njihovu dugogodišnju saradnju i izuzetne kolegijalne i prijateljske odnose, za ovaj se dio duše Zbornika 
posigurno nije mogla naći pozvanija ličnost da ga ispiše. To se posebno odnosi na iznimno sadržajan, akademski odmjeren i dostojanstven te jezičkostilski prefinjeno izbalansiranim tekst sjećanja koji naprosto oživljava lik Ilijasa Tanovića.

Glavni dio Zbornika podijeljen je u dvije tematske cjeline, od kojih prva nosi naslov Od leksikologije i leksikografije do kulture i prevođenja te obuhvata više od stotinu stranica tematski heterogenih tekstova. Druga tematska cjelina, pod nazivom Književni doticaji i posredovanja, nudi čitaocima sedamdesetak stranica teksta primarno književnohistorijske i književnoteorijske sadržine.

U prvoj tematskoj cjelini nalazi se sedam radova čiji su autori dominantno profesori i saradnici s Filozofskog fakulteta u Sarajevu - tri rada s Odsjeka za slavenske jezike i književnosti (Tanovićevog matičnog odsjeka), tri s Odsjeka za bosanski, hrvatski i srpski jezik (bratskog slavističkom i Tanoviću najbližeg saradničkog odsjeka) te jedan zajednički rad troje istaknutih lingvista s Ljubljanske Univerze, naših dragih Slovenaca s dugogodišnjim iskustvom plodotvorne i poštovanja vrijedne saradnje filozofskih fakulteta Sarajevskog i Ljubljanskog univerziteta, za koju je upravo Ilijas Tanović bio posebno zaslužan.

U drugoj tematskoj cjelini s naslovom Književni doticaji i posredovanja četiri su autorska rada - tri iz pera autora s Filozofskog fakulteta u Sarajevu, dok je autorica jedinog rada iz metodike s Filozofskog fakulteta $u$ Zadru.

Radovi u obje tematske cjeline poredani su po kriterijima abecednog reda autorskih prezimena.

Tako se prva tematska cjelina otvara zajedničkim radom slovenačkih autora Tatjane Balažic, Vojka Gorjanca i Vesne Požgaj Hadži pod naslovom Rječnik kao obiteljski album jedne kulture, u kojem se pažnja istraživača fokusira na predstavljanje rodnih odnosa u rječnicima bosanskoga jezika kao direktne refleksije nejednake distribucije moći u bosanskohercegovačkom društvu s nesumnjivim pokazateljima muške dominacije. Ovaj je rad za ovdašnju sredinu potpuno inovativan, ali je mnogo bitnije da sadrži nesporni potencijal inspiracije za sve autore budućih izdanja bosanskih rječnika. 
Zatim slijedi rad na ruskom jeziku Dženane Hajdarpašić s Odsjeka za slavenske jezike i književnosti Filozofskog fakulteta u Sarajevu pod naslovom Переводь русских фразеологизмов со словами «рука» и «нога» на боснийский язык и kojem autorica na bazi leksikografskih izvora dvaju jezika kontrastira bosanske i ruske frazeologizme selektirajući ih na potpune i nepotpune ekvivalente te na one koji se opisno prevode.

Rad pod naslovom Kulturno specifični elementi u romanu G. Jahine Zulejha otvara oči koji potpisuje autorica Amela Ljevo-Ovčina s Odsjeka za slavenske jezike i književnosti Filozofskog fakulteta u Sarajevu nesumnjivo pripada sferi lingvokulturoloških istraživanja. U konkretnom slučaju pažnju autorice Ljevo-Ovčine zaokupljaju riječi i izrazi iz tatarske kulture i duhovnosti s naglašenim prisustvom elemenata islamskog sakralnog stila koji čitaocima iz drugih kulturnih sredina zvuče egzotično i zanimljivo.

Pavel Ocepek, lektor slovenačkog jezika na Odsjeku za slavenske jezike i književnosti Filozofskog fakulteta u Sarajevu, svoj je doprinos ideji objave Zbornika radova dao kroz tekst pod naslovom $\mathrm{Ne}$, ne zapirajmo, odprimo! - o lektoratu slovenskega jezika na Oddelku za slovanske jezike in književnosti FF UNSA. Autor u svom radu nudi veoma zanimljive uporedne statističke podatke o nekadašnjem i trenutnom stanju slovenačkog lektorata na sarajevskom Filozofskom fakultetu, o rastućem zanimanju studenata za učenje slovenačkog jezika te o brojnim aktivnostima i sadržajima slovenačkog lektorata koje obogaćuju i afirmiraju rad cijelog Odsjeka.

Potom u Zborniku slijede tri rada autorica i autora s Odsjeka za bosanski, hrvatski i srpski jezik Filozofskog fakulteta u Sarajevu. Prvi rad, pod naslovom Elementi tradicionalnoga i modernoga u frazeologiji Ilijasa Tanovića, potpisuje Ismail Palić. U svom tekstu autor se posebno referira na Tanovićevu knjigu Frazeologija bosanskog jezika, čiji značaj za bosnističku lingvistiku posebno naglašava te u kojoj vidi i same temelje naučnog pristupa frazeološkom sistemu bosanskoga jezika. Iako su Tanovićevi pogledi na slavističku leksikologiju i frazeologiju dominantno tradicionalni, autor Palić otkriva i bitne elemente njegove otvorenosti prema savremenijim pristupima frazeologiji.

Drugi je rad Bernise Puriš pod nazivom Frazemi kao aksiološki i emocionalno-ekspresivni markeri u putopisnom diskursu, u kojem autorica svoje istraživanje temelji na odabranim zapisima bosanskohercegovačkih 
putopisaca iz 20. vijeka, proučavajući upotrebu frazeologizama s aspekta njihove sposobnosti iskazivanja vrijednosnih sudova. Ti vrijednosni sudovi po prirodi ovoga žanra imaju dominantno subjektivni karakter i inspirirani su intencijom putopisca da upotrebom emocionalno-ekspresivnih sredstava ostvari utjecaj na čitatelje/-ice.

Tekstom autorice Amele Šehović pod naslovom Etnokulturni stereotipi u frazemama bosanskoga jezika zatvara se prvi tematski blok radova u Zborniku. U svom radu autorica razmatra pitanje prisutnosti određenih etnostereotipa, istražuje sociolingvističke razloge njihovog postojanja te zapaža njihovu povezanost s određenim historijskim i društvenim okolnostima. Kod negativnih stereotipa razlozi se kriju najprije u strahu od Drugoga. Na formalnom planu, zaključuje autorica Šehović, ove frazeme najčešće imaju poredbenu strukturu unutar koje su predstavljeni narodi s uzajamnom historijskom povezanošću.

Druga tematska cjelina Zbornika (Književni doticaji i posredovanja) otvara se tekstom Tema smrti u umjetničkim minijaturama Ivana Sergejeviča Turgenjeva autorice Jelene Bavrke s Odsjeka za slavenske jezike i književnosti Filozofskog fakulteta u Sarajevu. Filozofski intonirana Turgenjevljeva promišljanja o prolaznosti života i o smrti autorica Bavrka analizira na korpusu njegove zbirke umjetničkih minijatura Senilia, predstavljajući mnogim čitaocima još nedovoljno poznatu vanserijsku književnoumjetnič$\mathrm{ku}$ vrijednost pjesmama u prozi ovog izuzetnog ruskog pisca.

Autorica Rafaela Božić s Filozofskog fakulteta u Zadru sadržaj Zbornika obogatila je svojim tekstom iz oblasti metodike nastave ruskog jezika pod naslovom Poezija u nastavi ruskog kao stranog jezika. U svom radu autorica ukazuje na izrazito nepovoljnu činjenicu da se u nastavi ruskog jezika sve manje koristi književnost, naročito poezija, te navodi primjere i metode mogućeg korištenja ruske poezije u nastavi s očekivanim višestruko povoljnim efektima.

Prijepori i poigravanja Vladimira Nabokova sa ruskom književnosti naslov je veoma zanimljivog teksta autora Srebrena Dizdara, inače profesora engleske i američke književnosti na Odsjeku za anglistiku Filozofskog fakulteta u Sarajevu, kojeg je svojim stavovima o ruskoj književnosti zaintrigirao ovaj kontroverzni ruski pisac. U svom radu autor Dizdar nas 
upoznaje s Nabokovljevim ambivalentnim odnosom prema ruskoj književnosti i posebno prema Dostojevskom.

I napokon, drugi tematski ciklus kao i Zbornik u cjelini završava izuzetnim radom autorice Adijate Ibrišimović-Šabić s Odsjeka za slavenske jezike i književnosti Filozofskog fakulteta u Sarajevu pod naslovom Skorikova adaptacija Tolstojeve Karenjine u Tanovićevom prijevodu (premijera 6.3.2007). U činjenici da je upravo Ilijas Tanović svojedobno preveo dramatizaciju Ane Karenjine u SARTR-u autorica Ibrišimović-Šabić pronašla je motiv da istraži i prouči sve njene postavke od 1927. godine pa sve do one posljednje, Skorikove inscenacije.

Zbornik radova posvećen Ilijasu Tanoviću predstavlja plod najplemenitijeg entuzijazma nastavnika i saradnika s Odsjeka za slavenske jezike i književnosti Filozofskog fakulteta Univerziteta u Sarajevu i njihovih organizacionih i autorskih napora. Ostvaren je uz podršku i pomoć autora - Tanovićevih radnih kolega, saradnika, prijatelja i poštovalaca - te predstavlja snažnu potvrdu dubokog naučnog, pedagoškog i ljudskog traga koji je ovaj izuzetni Čovjek ostavio iza sebe, naročito na svom matičnom odsjeku, ali i među saradnicima, kolegama i prijateljima s drugih odsjeka i drugih visokoškolskih ustanova u našoj zemlji i regionu.

Treba posebno naglasiti i činjenicu da je Zbornik od ideje do realizacije ostvaren uprkos vanrednim okolnostima dugotrajne pandemije planetarnih razmjera koja je izazvala dramatične poremećaje u funkcioniranju cijeloga svijeta, pa tako i naše zemlje. To se u kontekstu ove teme posebno odnosi na aspekte zabrane fizičkih kontakata i svih formi okupljanja članova Redakcije Zbornika i njegovih urednika. Stoga punu pažnju i respekt zaslužuje i Redakcija Zbornika na čelu s akademkinjom Marinom Katnić-Bakaršić i članicama Redakcije Dženanom Hajdarpašić i Jelenom Bavrkom, kao i urednici Zbornika - Amela Ljevo-Ovčina (glavna urednica), Safet Kešo (urednik za jezik) i Adijata Ibrišimović-Šabić (urednica za književnost).

Iznimno kvalitetne i veoma afirmativne recenzije iz pera Andree Lešić-Tomas i Mirele Omerović, kao i temeljit rad lektora - Azre Hodžić-Čavkić (bosanski, hrvatski i srpski), Ilje Tjapkova (ruski) i Pavela Ocepeka (slovenski) u značajnoj su mjeri doprinijeli da Zbornik radova U zrcalima sjećanja ostvari izuzetan kvalitet i onaj potencijal publikacije koji će ne samo 
privući pažnju stručne javnosti, nego i, vrlo vjerovatno, potaknuti novi istraživačko-stvaralački val, posebno u slavističkim krugovima.

Za lijepo idejno rješenje korica Zbornika i organizaciju dijela njegove tehničke pripreme zasluge i zahvalnost pripadaju Nadini Grebović-Lendo, šefici Biblioteke Filozofskog fakulteta.

Izdavač Zbornika je Filozofski fakultet Univerziteta u Sarajevu, visokoškolska ustanova kojoj na čast služi činjenica da je sve raspoložive resurse svojih službi i kadrova, riješenošću dekana Muhameda Dželilovića i njegovih najbližih saradnika, stavila na raspolaganje Redakciji i urednicima Zbornika. 